\title{
PERFORMANCE EVALUATION OF A WIRELESS CHARGING CONVERTER FOR ACTIVE IMPLANTABLE MEDICAL DEVICES
}

Sevilay CETIN*, Biomedical Engineering, Pamukkale University, Turkey, scetin@pau.edu.tr

(iD) https://orcid.org/0000-0002-9747-4821)

Yunus Emre DEMIRCI, Biomedical Engineering, Pamukkale University, Turkey, yunusdemirci1996@gmail.com (iD) https://orcid.org/0000-0001-8675-0619)

Onur BUYUKGUMUS, Electrical-Electronics Engineering, Pamukkale University, Turkey, onurbykgms@hotmail.com (iD) https://orcid.org/0000-0001-8254-544X)

Received: 26.05.2020, Accepted: 18.08.2020

Research Article

*Corresponding author

DOI: $10.22531 /$ muglajsci.742801

\begin{abstract}
This paper evaluates the performance of a wireless power transfer (WPT) converter for active implantable medical devices (AIMDS). The efficiency is the key parameter in the design of a WPT converter for charging of AIMDs. The compensation topology of a WPT system has an important role for high efficiency power transfer. Thus, this work analyses a WPT converter using LC/S hybrid compensation topology, for wireless charging of AIMDs, in terms of high efficiency power transfer. In the efficiency analyses, the WPT converter is tested by $3 D$ electromagnetic simulation software. The maximum efficiency is obtained as $72.33 \%$ while the output voltage is $4.2 \mathrm{~V}$ and the current is $0.45 \mathrm{~A}$. Finally, safety performance of proposed WPT converter is also evaluated based on specific absorption rate (SAR) analysis. The average peak spatial head/torso SAR produced by WPT converter is obtained as $0.0254 \mathrm{~W} / \mathrm{kg}$, which is lower than recommended restrictions.
\end{abstract}

Keywords: Wireless Power Transfer, Active Medical Device, Efficiency Performance, SAR

\section{VÜCUT İÇİNE YERLEŞTİIILEBİLEN AKTİF MEDÍKAL CİHAZLAR İÇİN KABLOSUZ ŞARJ EDEN BİR DÖNÜŞTÜRÜCÜNÜN PERFORMANS DEĞERLENDİRMESİ}

\begin{abstract}
Özet
Bu çalışma, vücut içine yerleştirilebilen aktif medikal cihazlar için kablosuz güç transferi (KGT) dönüştürücüsünün performansını değerlendirmektedir. Vücut içine yerleştirilebilen aktif medikal cihazların kablosuz güç transferi dönüştürücüsü tasarımında, verim önemli bir parametredir. Bu yüzden, bu çalışma LC/S hibrit kompansazyon topolojisini kullanan bir KGT dönüştürücüsünü yüksek verimli güç transferi açısından analiz etmektedir. Analiz çalışmasında, KGT dönüştürücüsü 3 boyutlu elektromanyetik simülasyon yazılımı ile test edilmiștir. Maksimum verim, çıkıs gerilimi 4,2 V ve akımı 0,45 A durumunda iken \%72,33 olarak elde edilmiştir. Son olarak, KGT dönüştürücüsünün emniyet performansı da özgül emilim oranı (SAR) analizi ile değerlendirilmiştir. Sunulan KGT dönüştürücüsü tarafindan üretilen ortalama gövde/kafa maksimum SAR değeri 0,0254 W/kg olarak, tavsiye edilen sınırlamaların altında elde edilmiştir.
\end{abstract}

Anahtar Kelimeler: Kablosuz Güç transferi, Aktif Medikal Cihaz, Verim Performansı, SAR

Cite

Cetin, S., Demirci, Y. E., Büyükgümüş, O. (2020). "Performance evaluation of a wireless charging converter for active implantable medical devices", Mugla Journal of Science and Technology, 6(2), 11-17.

\section{Introduction}

The importance of active implantable medical device (AIMD) increases day by day due to their life saver functions. AIMDs can improve or treat the needed functions of some organs with the use of electrical sources surgically placed into the body [1].
The main problem of AIMDs is the limited life time of their battery. The depletion time of a battery, depending on the role and operation conditions, changes between 5 and 15 years [2], [3]. Then, the battery has to be replaced with another surgery operation, which can cause to risks like infection, rejection, etc. [4]. The use of rechargeable battery allows recharging the battery and this results in extended lifetime for the battery. The 
wireless power transfer (WPT) method can be used to recharge the battery from the outside of the body [5][7]. The power transfer is provided with coupling coils, transmitter outside of the body and receiver inside of the body [8]-[11]. Therefore, at the outside of the body, a WPT converter providing power delivery to the receiver coil should be designed [12]-[14]. A WPT system for AIMDs should provide high efficiency and safety criteria to be implanted.

The compensation network has important role to provide high efficiency power transfer. The well-known compensation networks, in the literature, are seriesseries (SS), series-parallel (SP), parallel-parallel (PP) and parallel-series (PS) [15], [16]. PP and PS compensation networks are usually not preferred due to their poor efficiency [17]. In [5], a WPT system with SS and SP compensation network is presented for AIMDs. The power transfer efficiency capability of the WPT system is tested at $300 \mathrm{kHz}$ and $13.54 \mathrm{MHz}$ operation frequencies. SP network gives better efficiency at $300 \mathrm{kHz}$ and SS network is better at 13.56 $\mathrm{MHz}$ in terms of efficiency.

In order to increase power transfer efficiency of a WPT system, the hybrid compensation networks also exist in the literature [18]-[20]. In [18], a hybrid compensation network including additional inductor, capacitor and switch is presented to operate overall charge control mode of the battery. In [19], S/SP compensation network is presented to improve output voltage control capability of the WPT converter. In [20]-[21], doublesided LCC compensation network is presented to charge the electrical vehicle battery. Double-sided LCC compensation network improves the overall charge control modes of the battery and eliminates one inductor of hybrid topologies mentioned earlier. However, double-sided LCC compensation network is not good candidate for AIMDs application due to the number of components at the receiver side. An LCC-C compensation network is presented for pacemaker applications in [22], with series compensation of the receiver side. The design of the WPT system is implemented taken into consideration of real pacemaker device and pig tissues. In [23], an LC/S hybrid compensation network is presented to improve the response of constant current charge control mode. The operation of the compensation network is tested at $85 \mathrm{kHz}$ operation frequency. The constant current operation response of the LC/S topology is better than double-sided LCC compensation network. Besides, fewer component number presents size and cost advantages compared to LCC compensation network.

In this work, power transfer efficiency performance of a WPT converter with LC/S compensation network is evaluated for AIMDs applications. The basic principles and operation of the compensation network is presented. The receiver coil of WPT converter is modeled by 3D magnetic simulation software, taken into account of human tissues and real AIMD dimensions. Then efficiency and safety performance of the converter is tested by electromagnetic simulation at $300 \mathrm{kHz}$ operation frequency. The efficiency variation as function of different distances between transmitter and receiver coils is also extracted. The maximum efficiency is obtained as $72.33 \%$ at $8 \mathrm{~mm}$ distance while the output voltage is $4.2 \mathrm{~V}$ and the current is $0.45 \mathrm{~A}$. Finally, a safety performance evaluation is also presented based on electromagnetic field (EMF) produced by proposed WPT converter. According to the safety performance analysis, the average peak spatial head/torso specific absorption rate (SAR) produced by WPT converter is $0.0254 \mathrm{~W} / \mathrm{kg}$ and it is found within the recommended limits.

\section{LC/S Hybrid Compensation Network for WPT Converter}

The LC/S compensation network topology is shown in the circuit scheme of WPT converter, given in Figure 1. Where $\mathrm{L}_{1}-\mathrm{C}_{1}-\mathrm{C}_{\mathrm{S}}$ represent the compensation components for transmitter and receiver sides. $L_{P}$ and $L_{S}$ are the coupling coils providing energy transfer to the load. $\mathrm{D}_{\mathrm{R} 1}-\mathrm{D}_{\mathrm{R} 4}$ diodes produce the dc output voltage, $\mathrm{C}_{\mathrm{F}}$ is the filter capacitor and $R_{L}$ represents the load. $U_{1}$ is the input power source, $V_{B}$ is the battery voltage and $M$ is the mutual inductance between coupling coils.

The voltage gain of the converter can be extracted with $M$ model approach as given in [23] and it can be written as follows:

$$
G_{L C / S}=\frac{V_{B}}{V_{i n}}=\frac{2 \sqrt{2} j \omega M Z_{C 1}}{\pi Z_{S}\left(Z_{r}+j \omega L_{p}\right)\left(Z_{C 1}+j \omega L_{1}\right)} \times R_{a c} .
$$

Where $Z_{S}$ is the impedance of the receiver side, $Z_{r}$ is the reflected impedance from the receiver side. $Z_{\mathrm{C} 1}$ represents the equivalent impedance of $C_{1}, L_{P}$ and $Z_{r}$. These impedances can be defined as follows:

$$
\begin{gathered}
Z_{S}=R_{a c}+\frac{1}{j \omega C_{S}}+j \omega L_{s} \\
Z_{r}=\frac{\omega^{2} M^{2}}{Z_{S}} \\
Z_{C 1}=\frac{\left(Z_{r}+j \omega L_{p}\right) \frac{1}{j \omega C_{1}}}{Z_{r}+j\left(\omega L_{p}-\frac{1}{\omega C_{1}}\right)}
\end{gathered}
$$

Above, $\omega$ is the angular operational frequency, $R_{a c}$ represents the ac equivalent resistance of the rectifier, output filter and resistive load. Thus, $\mathrm{R}_{\mathrm{ac}}$ can be defined as below:

$$
R_{a c}=\frac{8}{\pi^{2}} R_{L} .
$$

The efficiency of WPT converter can be defined as

$$
\eta=\frac{P_{o}}{P_{\text {in }}} .
$$




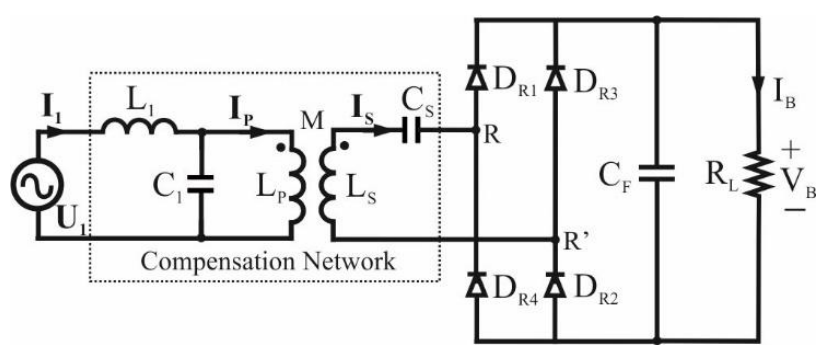

Figure 1. The circuit schematic of WPT converter with LC/S compensation for implantable AIMDs.

Where $\mathrm{P}_{\mathrm{o}}$ is the output power and it can be written as

$$
P_{o}=I_{S}{ }^{2} R_{a c} .
$$

Where Is is the current flowing through the receiver side and it can be defined as below:

$$
\mathbf{I}_{S}=\frac{j \omega M I_{P}}{Z_{S}} .
$$

The input power of the transmitter side is defined by

$$
P_{i n}=I_{1} \cdot V_{1} \cdot \cos \alpha_{i n} .
$$

Where $I_{1}$ is the input current of the transmitter side of WPT converter and it can be defined as follows:

$$
I_{1}=\frac{V_{1}}{Z_{\text {in }}} .
$$

$Z_{\text {in }}$ is the input impedance of WPT converter and defined as

$$
Z_{i n}=Z_{C 1}+j \omega L_{1} .
$$

The $\cos \alpha_{i n}$ is the phase angle between $V_{S}$ and $I_{S}$. The phase angel can be extracted from the input impedance, as given below:

$$
\cos \alpha_{i n}=\frac{\operatorname{Re}\left|Z_{i n}\right|}{\left|Z_{i n}\right|} .
$$

\section{Performance Evaluation of WPT Converter for AIMDs}

In the performance evaluation of the converter, the change of the output voltage is accepted between $3.8 \mathrm{~V}$ and $4.2 \mathrm{~V}$ taken into consideration of the most used Lithium-ion battery cells. The performance of the converter is tested with an electromagnetic simulation at $300 \mathrm{kHz}$ operation frequency. The coupling coils of the converter are modeled with 3D electromagnetic field simulation using finite element method (FEM). In order to see operation of the modeled coupling coils, a transient 3D field-electric common simulation is performed. Then a safety performance evaluation is carried out based on EMF produced by WPT converter. The design of coupling coils, transient simulation results and safety performance analysis are separately presented in the following sections.

\subsection{The Coupling Coils}

The design of coupling coils had an importance to improve the performance of power transfer efficiency. The coupling coils are designed in planar circular form. The external dimension of the transmitting coil is determined to be little larger than the receiving coil in case of any position alignment failure between coupling coils. A titanium case representing AIMD's shell is modeled and a thin ferrite film is placed between the receiver coil and titanium case in the simulation work, in order to decrease the effects of the induced Eddy current losses on the titanium case. The geometrical properties of the circular coupling coils are listed in Table I. In the determination of self-inductance of the receiver side, the ferrite film and the titanium case are taken into consideration. The transmitter coil is accepted in the air.

Table 1. The geometrical properties of circular coils.

\begin{tabular}{ccc}
\hline Parameters & Transmitting Coil & Receiving Coil \\
\hline External Diameter & $53.4 \mathrm{~mm}$ & $45.5 \mathrm{~mm}$ \\
Internal Diameter & $18.3 \mathrm{~mm}$ & $20.04 \mathrm{~mm}$ \\
Turns Number & 13 & 9 \\
Self-Inductance & $6.75 \mu \mathrm{H}$ & $4.66 \mu \mathrm{H}$ \\
\hline
\end{tabular}

\subsection{Field-Electric Co-Simulation Analysis and Results}

In this part, efficiency analysis of the WPT converter during the charge of the battery is evaluated. The circuit schematic and designed coupling coils are given in Figure 2. The modeled circular coupling coils are operated with 3D field-electric common simulation to obtain their transient response. The design specifications and used components in the simulation are given in Table II. The components of LC/S compensation are determined based on [23]. The input of the converter is fed from a sinusoidal ac source, $U_{1}$. The rectifier diodes with $0.8 \mathrm{~V}$ voltage drop are used in the simulation

work.

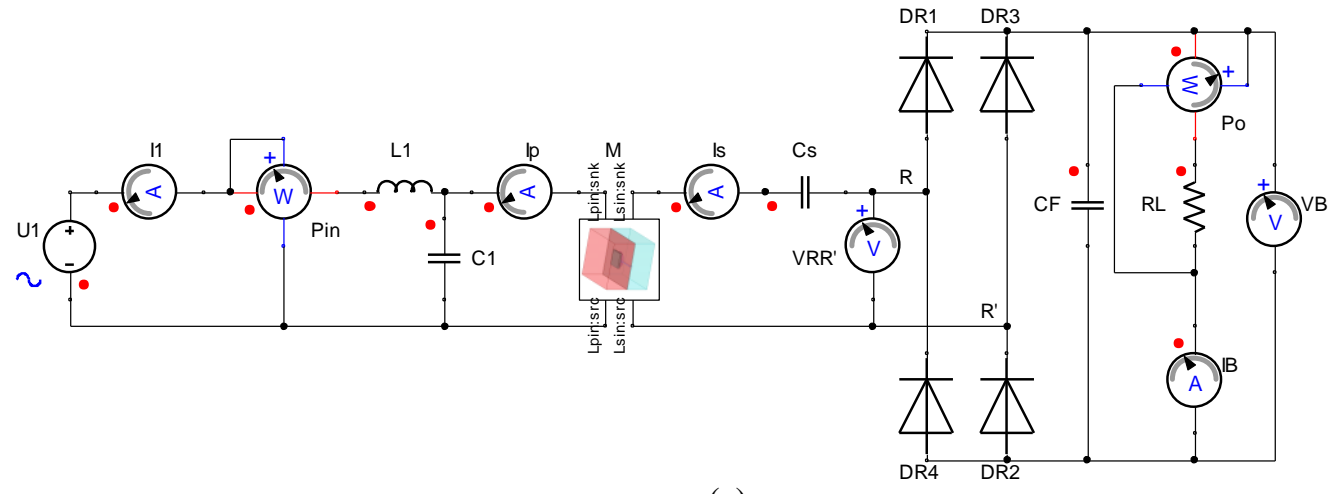

(a) 


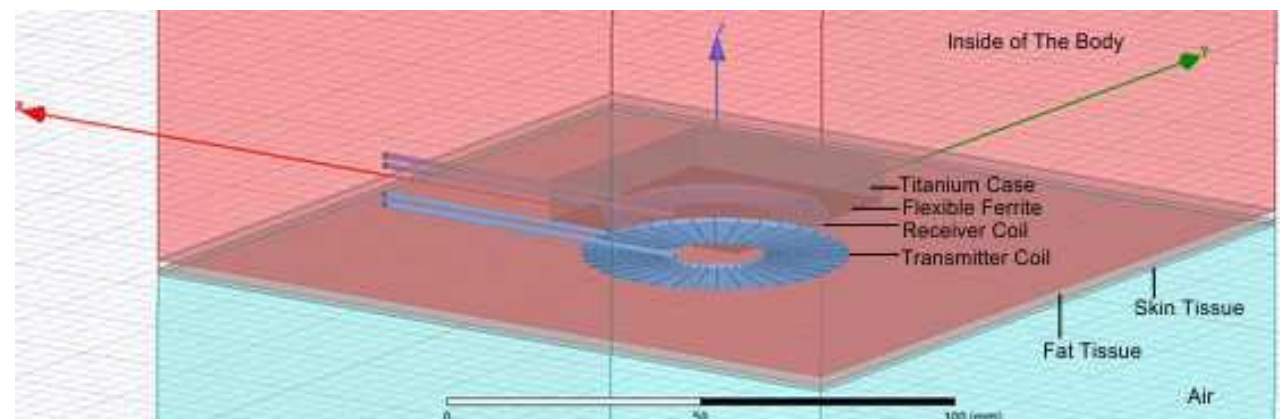

(b)

Figure 2. (a) The circuit schematic of the simulated WPT converter. (b) The circular coupling coils modeled 3D electromagnetic field simulation.

Table 2. Design specifications and used components in

\begin{tabular}{cc} 
the simulation work. \\
\hline $\mathrm{I}_{\mathrm{o}}=0.45 \mathrm{~A}, \mathrm{~V}_{\mathrm{B}}=3.8 \mathrm{~V}-4.2 \mathrm{~V}$ \\
$\mathrm{f}_{\mathrm{sw}}=300 \mathrm{kHz}, \mathrm{U}_{1}=2.59 \mathrm{~V}_{\mathrm{RMS}}$, \\
$\mathrm{k}=0.46$ \\
\hline $\mathrm{L}_{\mathrm{P}}$ & $6.75 \mu \mathrm{H}$ \\
$\mathrm{L}_{\mathrm{S}}$ & $4.66 \mu \mathrm{H}$ \\
$\mathrm{M}$ & $2.57 \mu \mathrm{H}$ \\
$\mathrm{L}_{1}$ & $6.75 \mu \mathrm{H}$ \\
$\mathrm{C}_{1}$ & $83.36 \mathrm{nF}$ \\
$\mathrm{C}_{\mathrm{S}}$ & $60 \mathrm{nF}$ \\
$\mathrm{C}_{\mathrm{o}}$ & $10 \mu \mathrm{F}$
\end{tabular}

The simulated voltage and current waveforms of the WPT converter are given in Figure3. Figure 3 (a) and (b) show the current and voltage waveforms of the input source and the rectifier. As shown in the simulated results, the voltage and the current of the input source and the rectifier are in same phase. Thus, WPT converter operates at resonant frequency and transfers the maximum power to the load. Figure 3(c) gives rectified current and the voltage waveforms that will charge the

battery.

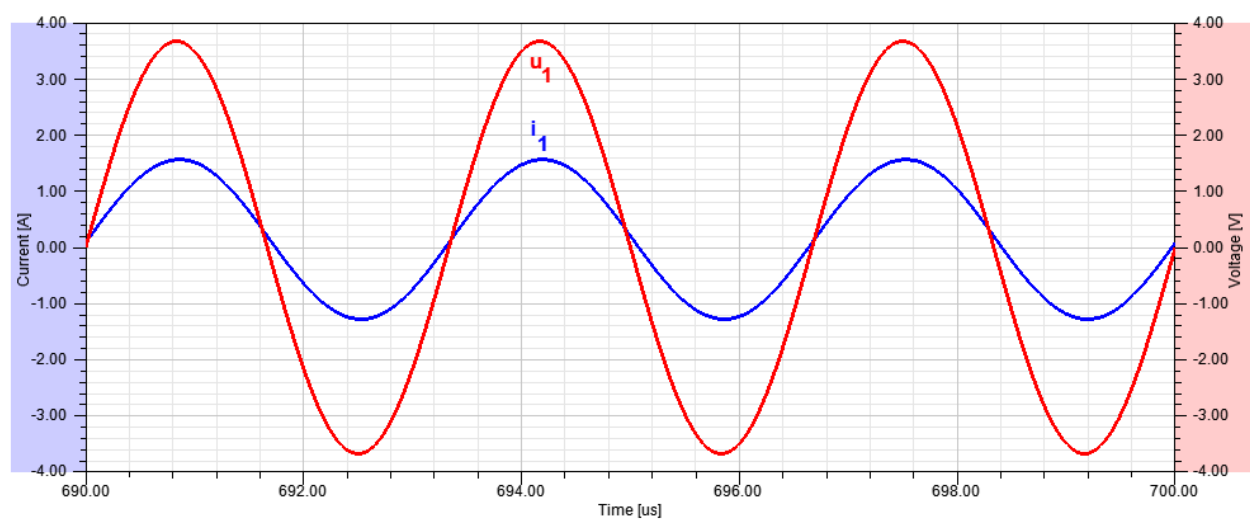

(a)

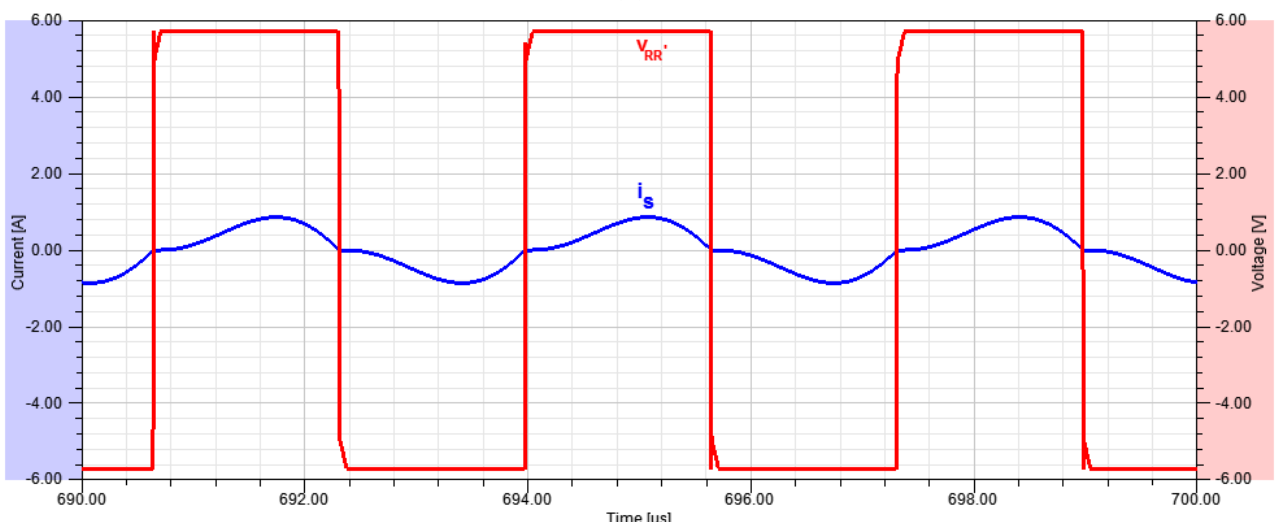

(b) 


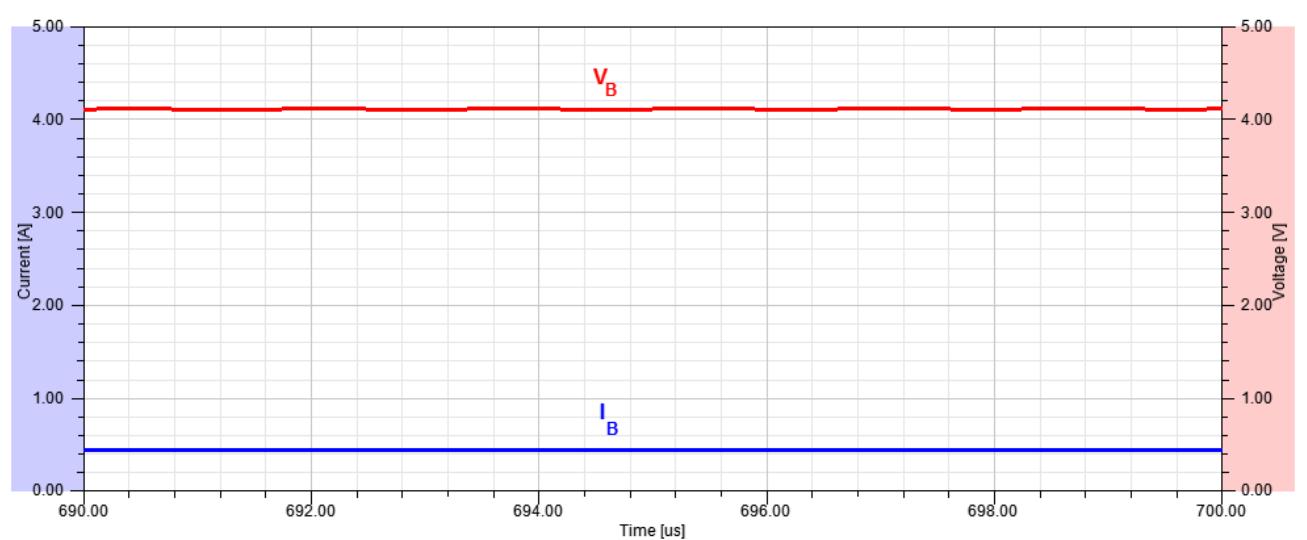

(c)

Figure 3. Simulated results. (a) The voltage and current waveforms of the input source ( $i_{1}$ and $u_{1}$ ). (b) The current waveform of receiving coil and the input voltage waveform of the rectifier (is and $v_{R R^{\prime}}$ ). (c) The rectified voltage and current waveforms of the WPT converter $\left(\mathrm{V}_{\mathrm{B}}\right.$ and $\left.\mathrm{I}_{\mathrm{B}}\right)$.

The maximum efficiency of the WPT converter is extracted as $72.33 \%$, while the output voltage is $4.2 \mathrm{~V}$ and the load current is $450 \mathrm{~mA}$. The variation of the efficiency for different distances is also extracted and the obtained results are given in Figure 4. As shown in Figure 4, efficiency values are decreased while the distance between coupling coils are increasing, as expected. The efficiency is very low after $30 \mathrm{~mm}$ distance. The mutual inductance value between the transmitter and the receiver coils also decreases with the increase of the distance, as shown in Figure 5. Therefore, WPT converter with LC/S compensation can be used for active medical devices implanting until 30 $\mathrm{mm}$ depth into the body.

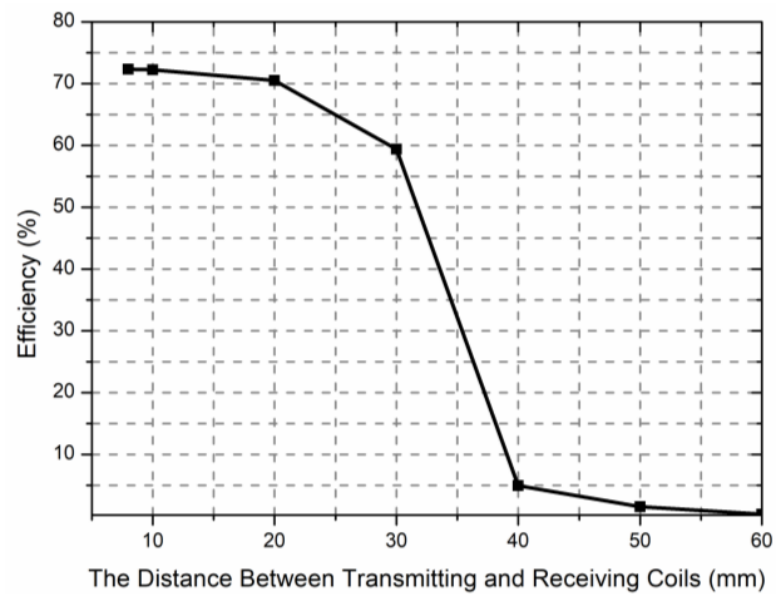

Figure 4. The efficiency variation of WPT converter based on distance variation between two coupling coils. $\mathrm{V}_{\mathrm{B}}=4.2 \mathrm{~V}, \mathrm{I}_{\mathrm{B}}=450 \mathrm{~mA}$.

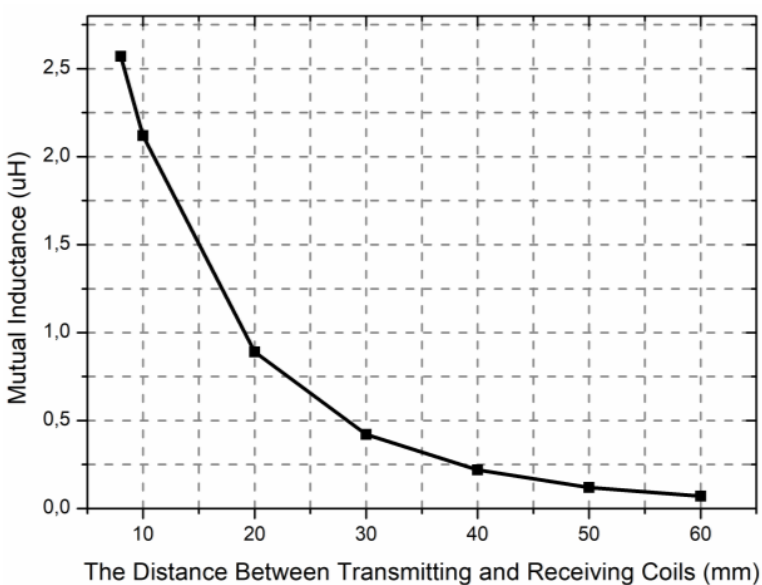

Figure 5. The mutual inductance variation of WPT converter based on distance variation between two coupling coils.

\subsection{Safety Evaluations}

After efficiency evaluations of WPT converter, the reliability of the system is analyzed based on SAR. In the safety analysis, Commission on Non-Ionizing Radiation Protection (ICNIRP) and the Institute of Electrical and Electronics Engineers (IEEE) presenting basic limits for SAR effects are taken into consideration [24], [25]. The simulated currents, 1.12 A through transmitting coil and 0.6 A through receiving coil, are used for the simulations of SAR analysis.

In order to evaluate the safety performance of WPT converter, an upper body 3D model including head and torso, exist in 3D simulation software, is used. The distance between the receiving and the transmitting coils is accepted as $8 \mathrm{~mm}$. The analysis results of average SAR for $10 \mathrm{~g}$ human tissues is given in Figure 6. The produced SAR by WPT converter and its comparison with recommended limits are given in Table III. According to analysis results, for $10 \mathrm{~g}$ human tissue, average peak spatial SAR produced by WPT converter is $0.0254 \mathrm{~W} / \mathrm{kg}$ and this value is much lower than the 2 $\mathrm{W} / \mathrm{kg}$ recommended by ICNRP and IEEE. 


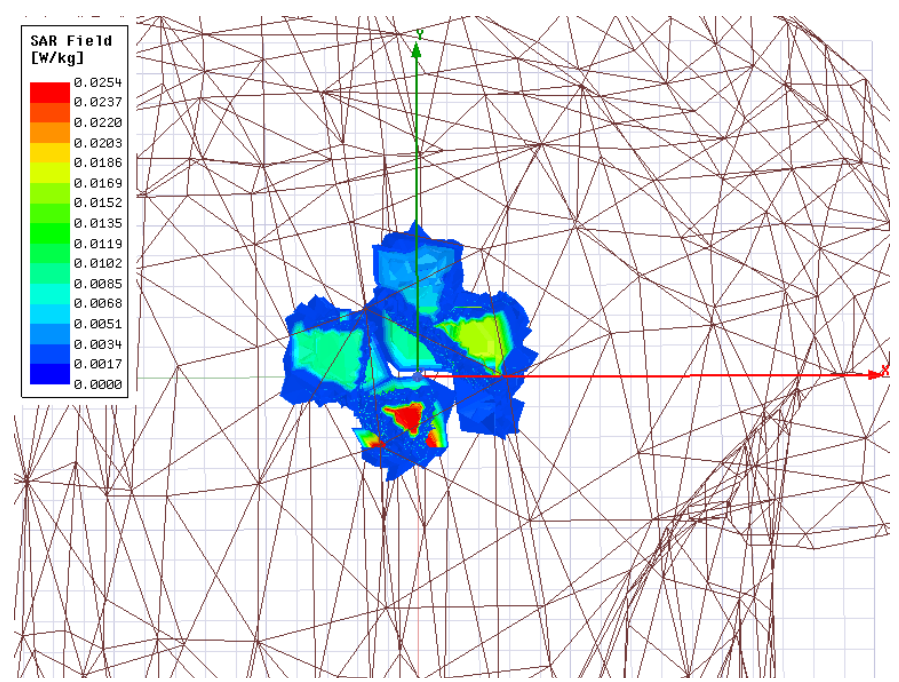

Figure 6. The SAR analysis, in the human tissues, obtained by upper body 3D FEM.

Table 3. The localized head/torso SAR produced by WPT converter and recommended SAR limits.

The Localized Head/Torso SAR Values

\begin{tabular}{lll}
\hline \multicolumn{2}{c}{ Basic Restrictions } & \multicolumn{1}{c}{$\begin{array}{c}\text { Produced by WPT } \\
\text { converter }\end{array}$} \\
\hline ICNRP & IEEE & 3D FEM Simulation \\
\hline $2 \mathrm{~W} / \mathrm{kg}$ & $2 \mathrm{~W} / \mathrm{kg}$ & $0.0254 \mathrm{~W} / \mathrm{kg}$ \\
$100 \mathrm{kHz}-6 \mathrm{GHz}$ & $100 \mathrm{kHz}-6 \mathrm{GHz}$ & $300 \mathrm{kHz}$ \\
\hline
\end{tabular}

In the operation of the presented WPT converter, induced Eddy currents on the AIMD's shell reduces the induced voltage across the receiving coil. Therefore, the required energy transferred from the transmitting coil should be increased in order to provide the charge of the battery. However, increased energy from the transmitting coil can cause to damage human tissues. A thin ferrite film can help to reduce the Eddy current losses on the AIMD's shell [22]. If ferrite film is not enough for magnetic shielding, precise implant position of receiving coil can be determined as presented in [26], in the real clinical applications of the presented WPT converter.

\section{Conclusion}

In this work, a WPT converter with LC/S compensation is presented for AIMDs. The performance of the converter is evaluated based on power transfer efficiency. Transmitting and receiving coils are magnetically modeled and an electric-field common simulation is carried out to obtain transient response of the converter. The simulation results shows the power transfer capability of the WPT converter. The power transfer is provided with approximately zero phase angle between voltage and current of the input source and the rectifier. The maximum efficiency is obtained as $72.33 \%$ at full load condition. The decrease of the efficiency, with the increase of distance, is validated by simulation work. According to safety performance of the WPT converter, average peak spatial SAR produced by the WPT converter is obtained as $0.0254 \mathrm{~W} / \mathrm{kg}$ and within the limits recommended by ICNRP and IEEE.

\section{Acknowledgment}

This work is supported by Pamukkale University under grant number 2019FEBE064.

\section{References}

[1] CEN EN 45502-1, "Active Implantable Medical Device. Part1: General Requirements for Safety, Marking and Information to be provided by the Manufactures", 1997.

[2] Santini, M., Cappato, R., Andresen, D., Brachmann, J., Davies, D.W., Cleland, J., Filippi, A., Gronda, E., Hauer, R., Steinbeck, G., Steinhaus, D., "Current state of knowledge and experts perspective on the subcutaneous implantable cardioverterdefibrillator," J. Interventional Cardiac Electrophysiol., Vol. 25: No. 3, 83-88, 2009.

[3] Drews, J., Fehrmann, G., Staub, R., and Wolf, R., "Primary batteries for implantable pacemakers and defibrillators", Journal of Power Sources, Vol. 97-98, 747-749, 2001.

[4] Klug, D., Balde, M., Pavin, D., Hidden-Lucet, F., Clementy, J., Sadoul, N., Rey, J.L., Lande, G., Lazarus, A., Victor, J., Barnay, C., Grandbastien, B. and Kacet, S., "Risk Factors Related to Infections of Implanted Pacemakers and Cardioverter-Defibrillators Results of a Large Prospective Study", Circulation, Vol.116, No.12, 1349-1355, 2007.

[5] Campi T., Cruciani S., Palandrani F., De Santis V., Hirata A. and Feliziani M., "Wireless Power Transfer Charging System for AIMDs and Pacemakers", IEEE Transactions on Microwave Theory and Techniques, Vol.64, No.2, 633- 642, 2016.

[6] Lu, Y. and Ki, W.H., "A $13.56 \mathrm{MHz}$ CMOS Active Rectifier With Switched-Offset and Compensated Biasing for Biomedical Wireless Power Transfer Systems", IEEE Transactions on Biomedical Circuit and Systems, Vol.8, No.3, 334-344, 2014.

[7] Ahire, D.B. and Gond, V.J., "Wireless Power Transfer System for Biomedical Application: A Review", International Conference on Trends in Electronics and Informatics", 2017, 135-140.

[8] Xue, R.F., Cheng, K.W. and Je, M., "High-Efficiency Wireless Power Transfer for Biomedical Implants by Optimal Resonant Load Transformation", IEEE Transactions on Circuits and Systems - I:Regular Papers, Vol.60, No.4, 867-874, 2013.

[9] Yi, Y., Buttner, U., Fan, Y. and Foulds, I.G., "Design and optimization of a 3-coil resonance-based wireless power transfer system for biomedical implants", International Journal of Circuit Theory and Applications, Vol.43, No.10, 1379-1390, 2015.

[10] Rakhyani, A.K.R., Mirabbasi, S. and Chiao, M., "Design and Optimization of Resonance-Based Efficient Wireless Power Delivery Systems for Biomedical Implants", IEEE Transactions on Biomedical Circuits and Systems, Vol.5, No.1, 48-63, 2011. 
[11] Cha, H.K., Park, W.T. and Je, M., "A CMOS Rectifier With a Cross-Coupled Latched Comparator for Wireless Power Transfer in Biomedical Applications", IEEE Transactions on Circuits and Systems - II: Express Briefs, Vol.59, No.7, 409-413, 2012.

[12] Joun, G.B. and Cho, B.H., "An energy transmission system for an artificial heart using leakage inductance compensation of transcutaneous transformer", IEEE Transactions on Power Electronics, Vol.13, No.6, 1013-1022, 1998.

[13] Chen, Q., Wong, S.C., Tse, C.K. and Ruan, X., "Analysis, design, and control of a transcutaneous power regulator for artificial hearts," IEEE Trans. Biomed. Circuits Syst., Vol.3, No.1, 23-31, 2009.

[14] Li, X., Zhang, H., Peng, F., Li, Y., Yang, T., Wang, B. and Fang, D., "A Wireless Magnetic Resonance Energy Transfer System for Micro Implantable Medical Sensors" Sensors (Basel), Vol.12, No.8, 10292-10308, 2012.

[15] Xiao, C.Y., Wei, K.Z., Liu, F., and Ma, Y.X., "Matching capacitance and transfer efficiency of four wireless power transfer systems via magnetic coupling resonance," Int. J. Circuit Theory Appl., Vol.45, No.6, 811-831, 2017.

[16] Zhou, W. and Ma, H., "Design considerations of compensation topologies in ICPT system", IEEE Applied Power Electronics Conference and Exposition, 2007, 985-990.

[17] Joy, E.R., Kushwaha, B.K.; Rituraj, G. and Kumar, P., "Analysis and Comparison of Four Compensation Topologies of Contactless Power Transfer System", 4th International Conference on Electric Power and Energy Conversion Systems (EPECS), 2015, 1-6.

[18] Qu, X.H., Han, H., Wong, S.C., Tse, C.K. and Chen, W. "Hybrid IPT topologies with constant-current or constant-voltage output for battery charging applications", IEEE Trans. on Power Electronics, Vol.30, No.11, 6329-6337, 2015.

[19] Hou, J., Chen, Q., Wong, S.C., Tse, C.K. and Ruan, X., "Analysis and Control of Series/Series-Parallel Compensated Resonant Converter for Contactless
Power Transfer", IEEE Trans. on Power Electronics, Vol.3, No.1, 124-136, 2015.

[20] Li, S., Li, W., Deng, J., Nguyen, T.D. and Mi, C.C., "A double-sided LCC compensation network and its tuning method for wireless power transfer," IEEE Trans. on Veh. Technol., Vol.64, No.6, 2261-2273, 2014.

[21] Vu, V.B., Tran, D.H. and Choi, W., "Implementation of the Constant Current and Constant Voltage Charge of Inductive Power Transfer Systems With the Double-Sided LCC Compensation Topology for Electric Vehicle Battery Charge Applications", IEEE Transactions on Power Electronics, Vol.33, No.9, 7398-7410, 2018.

[22] Xiao, C., Cheng, D. and Wei, K., "An LCC-C Compensated Wireless Charging System for Implantable Cardiac Pacemakers: Theory, Experiment, and Safety Evaluation", IEEE Transactions on Power Electronics, Vol.33, No.6, 4894-4905, 2018.

[23] Wang, Y., Yao, Y., Liu, X., Xu, D., Cai, L., "LC/S Compensation Topology and Coil Design Technique for Wireless Power Transfer", IEEE Transactions on Power Electronics, Vol.33, No.3, 2007-2024, 2018.

[24] International Commissionon Non-Ionizing Radiation Protection, "Guidelines for limiting exposure to time-varying electric, magnetic, electromagnetic fields (up to $300 \mathrm{GHz}$ )," Health Phys., vol. 74, no. 4, 494-522, 1998.

[25] IEEE Standard for Safety With Respect to Human Exposure to Radio Frequency Electromagnetic Fields, $3 \mathrm{kHz}$ to $300 \mathrm{GHz}$, IEEE Standard C95.1, 2005.

[26] Xiao, C., Wei, K., Cheng, D. and Liu, Y., "Wireless Charging System Considering Eddy Current in Cardiac Pacemaker Shell: Theoretical Modeling, Experiments, and Safety Simulations", IEEE Transactions on Industrial Electronics, Vol.64, No.5, 3978-3988, 2017. 